\title{
Beverages formulated with whey protein and added lutein
}

\author{
Juliana de Cássia Gomes Rocha ${ }^{1 *}$ Adriana Corrêa Mendonça ${ }^{1}$ Kéllen Wanessa Coutinho Viana ${ }^{1}$ \\ Mariza de Paiva Maia ${ }^{1}$ Antônio Fernandes de Carvalho ${ }^{1}$ Valéria Paula Rodrigues Minim ${ }^{1}$ Paulo César Stringheta $^{1}$
} ${ }^{1}$ Departamento de Tecnologia de Alimentos, Universidade Federal de Viçosa (UFV), Av. Ph Rolfs, s/n, 36570-000, Viçosa, MG, Brasil.
E-mail: juliana.rocha@ufv.br. "Corresponding author.

ABSTRACT: This study aimed to develop and characterize beverages formulated with whey protein and added lutein. Beverages formulated with 0.5 (F1), 2.0 (F2), 4.0 (F3) and 6.0\% w/v (F4) whey protein were physicochemically and microbiologically characterized, and sensory evaluated. The physicochemical analyses indicated that the protein content significantly changed (P<0.05) the acidity values, soluble solids and the colorimetric coordinates, making possible to adjust mathematical models for all these variables. Microbiological analyses showed no significant contamination $(P<0.05)$ during processing that would compromise drinks quality of the drinks. Carotenoid content and the antioxidant activity did not change significantly ( $p>0.05)$ with increased protein content. The F2 formulation showed the highest sensory acceptance. Beverages offer a promising alternative to whey use and enhance the value of the product by the addition of lutein.

Key words: antioxidant activity, lutein, proteins, protein drink, sensory acceptance, whey.

Bebidas formuladas com proteínas de soro de leite e adicionadas de luteína

RESUMO: Este estudo teve como objetivo desenvolver e caracterizar bebidas formuladas com proteinas de soro de leite adicionadas de luteina. Bebidas formuladas com 0,5 (F1), 2,0 (F2), 4,0 (F3) e 6,0\% m/v (F4) de proteinas de soro caracterizadas fisico-quimicamente e microbiologicamente e, avaliadas sensorialmente. As análises fisico-químicas indicaram que o teor de proteína alterou significativamente $(P<0,05)$ os valores de acidez, sólidos solúveis e as coordenadas colorimétricas, foi possível ajustar modelos matemáticos para todas essas variáveis. As análises microbiológicas mostraram contaminação não significativa $(P<0,05)$ durante o processamento que poderia comprometer a qualidade das bebidas. Os teores de carotenoides e a atividade antioxidante não variaram significativamente (P>0,05) com o aumento do teor de proteína. A formulação F2 apresentou a maior aceitação sensorial. As bebidas são uma alternativa promissora para o uso do soro de leite e aumentam o valor agregado do produto pela adição de luteína.

Palavras-chave: atividade antioxidante, luteina, proteinas, bebida proteica, aceitação sensorial, soro de leite.

\section{INTRODUCTION}

For years there was a great effort to transform high whey volumes generated as a by-product of cheese industry into a product suitable for food use. However, nowadays the whey is no longer considered a by-product but rather a co-product of the dairy industry (ALVES et al., 2014). The new direction toward whey utilization is due to one of its primary constituents, proteins.

Whey proteins have a biological value higher than proteins primarily because of their high content of essential and branched chain (isoleucine, leucine and valine) amino acids. These particular amino acids stimulate intracellular pathways associated with muscle protein synthesis, cell repair, construction and repair of bone and a series of metabolic processes (KATSANOS et al., 2006; PESCUMA et al., 2010). Whey protein is used as an ingredient to increase the nutritional value of fortified food products, such as beverages and soups, and as a dietary supplement for people who require a higher daily intake of proteins, such as athletes and the elderly (CHILDS et al., 2007).

Lutein is a natural colorant who belongs to the group of carotenoids, of xanthophylls's class, and is known as the macular carotenoid yellow pigment, a potent antioxidant that prevents tissue damage caused by free radicals (STRINGHETA et al., 2006). It is concentrated in the yellow spot of the eye retina, also known as the macula lutea, which acts as a blue light filter, and; therefore, can contribute to the prevention of age-related macular degeneration and other eye diseases, such as cataracts. Lutein can be found naturally in dark green leafy vegetables, particularly spinach, kale, broccoli, as well as squash, fruit and egg yolk. When the dietary intake of lutein is insufficient, it can be supplemented by dietary supplements or foods that are enriched with this compound (ROBERTS et al., 2009; RODIĆ et al., 2012). 
The development of a beverage constituted of whey proteins using lutein as colorant becomes a great ally for individuals seeking health and wellness, besides attending specific nutritional needs. In this context, the objective of the current study was to develop, characterize and sensory evaluate beverages formulated with whey protein and added lutein.

\section{MATERIALS AND METHODS}

\section{Microfiltration and ultrafiltration of cheese whey}

The whey was subjected to centrifugation, microfiltration and ultrafiltration processes. The whey was microfiltered at $50^{\circ} \mathrm{C}$ using a Tetra $\mathrm{Pak}^{\odot}$ processing system (France) equipped with a tubular ceramic Membralox membrane $(0.8 \mu \mathrm{m}$ pore size, $0.24 \mathrm{~m}^{2}$ total membrane area). The tangential flow was maintained at $7.2 \mathrm{~m} \cdot \mathrm{s}^{-1}$ permeation speed and 0.5 bar transmembrane pressure. The obtained whey permeate contained $0.85 \% \mathrm{w} / \mathrm{v}$ protein.

Ultrafiltration of the whey was performed at $35^{\circ} \mathrm{C}, 2.1-8.3$ bars, in a pilot plant (WGM Systems), using an open system and a spiral type polysulfone membrane (Koch Membranes) with a $10 \mathrm{kDa}$ molar mass cutoff and $3.0 \mathrm{~m}^{2}$ filtration area. The obtained whey retentate contained $3.0 \% \mathrm{w} / \mathrm{v}$ protein.

\section{Development of formulations}

Beverage formulations were prepared in triplicate at $0.5,2.0,4.0$ and $6.0 \% \mathrm{w} / \mathrm{v}(\mathrm{F} 1, \mathrm{~F} 2, \mathrm{~F} 3$ and $\mathrm{F} 4$, respectively) whey protein. The whey permeate $(0.85 \% \mathrm{w} / \mathrm{v}$ protein), and whey retentate $(3.0 \%$ protein) were used to formulate the 0.5 and $2.0 \% \mathrm{w} / \mathrm{v}$ protein beverages, respectively, while the 4.0 and $6.0 \% \mathrm{w} / \mathrm{v}$ protein formulations were prepared with commercial whey protein concentrate (WPC60). Proportion of retentate, permeate and WPC60 used in the formulations was pre-determined based on the initial protein content of each raw material. These ingredients were added to the remaining constituents, namely mineral water, sugar $(15 \% \mathrm{w} / \mathrm{v})$, passion fruit pulp $(10 \% \mathrm{w} / \mathrm{v})$, arabic gum $(0.45 \% \mathrm{w} / \mathrm{v})$, potassium sorbate $(0.03 \% \mathrm{~m} / \mathrm{v})$ and passionfruit flavor. Formulations were then acidified with citric acid to $\mathrm{pH} 4.0$ and heated at $63^{\circ} \mathrm{C}$ for $30 \mathrm{~min}$ before adding $3.2 \mathrm{mg}$ of lutein powder (extracted from Tagetes erecta flowers, DSM Nutritional Products) per $100 \mathrm{~g}$ of beverage. After fabrication, the beverages were stored at $5 \pm 1^{\circ} \mathrm{C}$ until analysis.

\section{Physicochemical properties}

The $\mathrm{pH}$, titratable acidity and total soluble solids (TSS) were determined according to the standards of the Institute Adolfo Lutz (IAL 2008).
Protein concentration was obtained by the Kjeldahl method, using a conversion factor of 6.38 , based on the International Dairy Federation Standard 20B (IDF 1993). The color was measured in the CIELAB system $\left(\mathrm{L}^{*}, \mathrm{a}^{*}\right.$ and $\left.\mathrm{b}^{*}\right)$ with the D65 illuminant and a $10^{\circ}$ viewing angle using a colorimeter (HunterLab, model ColorQuest XE, Reston, USA). The hue angle $\left(\mathrm{h}^{*}\right)$ and saturation $\left(C^{*}\right)$ were respectively calculated from the $\mathrm{a}^{*}$ and $b^{*}$ values according to the equations below:

$$
\begin{aligned}
& h^{*}=\arctan \left(\frac{b^{*}}{a^{*}}\right) \\
& C^{*}=\sqrt{a^{* 2}+b^{* 2}}
\end{aligned}
$$

\section{Extraction of lutein from the formulations and its quantification}

Ethanol $(20 \mathrm{~mL}, 95 \%)$ was added to $10 \mathrm{~g}$ of each formulation and then the samples centrifuged at $2500 \mathrm{~g}$ for $5 \mathrm{~min}$. The supernatant was reserved, and ethanol $(10 \mathrm{~mL}, 95 \%)$ added to the precipitate and recentrifuged. This procedure was repeated two more times. The total supernatant was divided into two aliquots of $25 \mathrm{~mL}$ and extraction performed by adding $50 \mathrm{~mL}$ of acetone with stirring for 1 minute and transferred to a separatory funnel containing $45 \mathrm{~mL}$ of petroleum ether to each aliquot. Mixture of acetone, lutein and petroleum ether was washed successively with distilled water. The mixture of lutein and petroleum ether obtained from the two extractions was collected in a $250 \mathrm{~mL}$ round-bottom flask and dried on vacuum rotary evaporator (IKA RV 10 , LabScience) at $38^{\circ} \mathrm{C}$, then re suspended in $10 \mathrm{~mL}$ of 99.8\% absolute ethanol and stored under refrigeration until analysis. Carotenoid content was determined with the aid of a spectrophotometer (Shimadzu, model UVVis $1601 P C$ ) at $445 \mathrm{~nm}$, corresponding to the wavelength of maximum absorption for lutein in diluted ethanol (99.8\%), measured in a $1 \mathrm{~cm}$ cuvette (RODRIGUEZAMAYA, 2001). The molar absorption coefficient of $2550 \mathrm{~L} \cdot \mathrm{cm}^{-1} \cdot \mathrm{g}^{1}$ was used. The total carotenoid content was calculated according to the following equation and expressed as milligrams of lutein per $100 \mathrm{~g}$ of beverage:

$$
\begin{aligned}
& x(m g)=\frac{A \cdot y(m L) \cdot 10^{3}}{A_{1 c m}^{10} \cdot 100} \\
& x(m g / 100 g)=\frac{x(m g)}{\operatorname{sample}(g)} \cdot 100 \\
& x=\text { lutein content }(\mathrm{mg}) \\
& A=\text { absorbance at } 445 \mathrm{~nm} \\
& A_{1 \mathrm{~cm}}^{1 \%}=\text { molar absorptivity coefficient in absolute ethanol } \\
& y(m L)=\text { volumetric flask volume. }
\end{aligned}
$$

\section{Antioxidant activity in vitro}

The antioxidant activity of the lutein extracted from the beverages was investigated using 
the TEAC (Trolox equivalent antioxidant capacity) assay, with the ABTS (2,2'-azinobis-3-ethylbenzothiazoline-6-sulfonate) radical, according to the method described by RE et al. (1999). Results were expressed as $\mu \mathrm{mol} \cdot \mathrm{L}^{-1}$ Trolox per gram of beverage.

\section{Microbiological analysis}

The facultative anaerobes, aerobic mesophiles, coliforms and Escherichia coli were enumerated. The air quality at the factory during the production steps was determined by the sedimentation method on plates (WEHR \& FRANK, 2004). Staphylococcus aureus was enumerated according to the Association of Official Analytical Chemists standard (AOAC 2001).

\section{Sensory acceptability}

A sensory acceptance test was conducted at the Sensory Analysis Laboratory of UFV Food Technology Department (Brazil) using a nine-point hedonic scale. The 112 consumer testers were placed in individual cabins and simultaneously evaluated the color and overall impression (MINIM, 2013) of the passion fruit protein beverages (F1, F2, F3 and F4).

\section{Statistical analysis}

The effects of protein content on the physicochemical properties and antioxidant activity were evaluated by simple regression analysis, at a $5 \%$ significance level. The sensory acceptability results were assessed by principal component analysis (PCA) through internal preference map (MINIM, 2010). Statistical analyses were performed using SAS version 9.1 (SAS Institute, Cary, NC, USA) licensed to Universidade Federal de Viçosa.

\section{RESULTS AND DISCUSSION}

Physicochemical properties and antioxidant activity Table 1 showed the physicochemical properties and antioxidant activity of the beverages. There was a significant effect $(\mathrm{P}<0.05)$ of the protein content on all the colorimetric coordinates. Lightness $\left(\mathrm{L}^{*}\right)$ of beverages increased with increasing protein content. First- and second-degree models were tested for the $\mathrm{L}^{*}$ and $\mathrm{a}^{*}$ coordinates but showed either a significant lack of adjustment $(\mathrm{P}<0.05)$ or non-significant regression parameters $(\mathrm{P}>0.05)$. Hence, neither model was considered adequate to describe these system parameters. In contrast, the influence of protein content on the values of $b^{*}, h^{*}$ and $C^{*}$ could be statistically modeled according to the following equations:

$\mathrm{b}^{*}=-1.4003 . \mathrm{prt}^{2}+12.9335 . \mathrm{prt}+20.6940$

$\mathrm{R}^{2}=0.9992$ $\mathrm{h}^{*}=-0.3522 . \mathrm{prt}^{2}+3.6466 . \mathrm{prt}+68.9883$
$\mathrm{C}^{*}=-1.3927 . \mathrm{prt}^{2}+12.7767 . \mathrm{prt}+22.3851$

$\mathrm{R}^{2}=0.9989$

where prt is protein content $(\% \mathrm{w} / \mathrm{v})$.

The equations revealed that the maximum values of $\mathrm{b}^{*}$ and $\mathrm{C}^{*}$ corresponded to a protein content of $5.0 \% \mathrm{w} / \mathrm{v}$. Thus, a protein content higher than $5.0 \%$ $\mathrm{w} / \mathrm{v}$, contributed to a decrease in the yellow color of beverages. For the hue angle $\left(h^{*}\right)$, the respective equation showed a maximum value at $6.0 \% \mathrm{w} / \mathrm{v}$ protein, above this value, $h^{*}$ values decreased, distancing from the coordinate $b^{*}$, what indicated decrease in yellow color at higher protein content. Beverages had high $\mathrm{b}^{*}$ and $\mathrm{C}^{*}$ values, indicating a yellow product with a high color saturation. Hence, even after processing, lutein remained predominant.

There was no significant effect $(\mathrm{P}>0.05)$ of protein content on the $\mathrm{pH}$ of the formulations. However, for the acidity and TSS, the effect was significant $(\mathrm{P}<0.05)$. The variation in TSS was caused by the increasing amount of added protein, since the base formulation was maintained for all beverages, the protein content directly altered the solids concentration. The influence of protein content on the acidity and TSS was statistically modeled by the equations shown below:

TSS $=0.9781 . p r t+21.0181$

Acidity $=0.1090$.prt +0.3274

$\mathrm{R}^{2}=0.9897$

where prt is protein content $(\% \mathrm{w} / \mathrm{v})$.

With an increase in protein content, there was a proportional increase in acidity. The presence of amino acids having specific structures, that is, have their positive charge side groups as lysine, histidine and arginine, as well as the addition of citric acid to the formulations, contributed to this change in acidity (NELSON \& COX, 2004). Beverages formulated with increasing amounts of protein required a greater amount of citric acid to reach the desired $\mathrm{pH}$. SILVA (2012b) observed a similar change in acidity when replacing the fat in ice cream with whey proteins, due to the $\mathrm{pH}$ being below the isoelectric point of the whey proteins. However, the $\mathrm{pH}$ remained constant due to the so-called buffer effect, as these proteins are structurally stable over a broad pH range (TAULIER \& CHALIKIAN, 2001; SGARBIERI, 2005).

The total carotenoid and antioxidant activity did not change significantly $(p>0.05)$ with the increase in protein content of the formulations (Table 1). Approximately $75-83 \%$ of the added lutein was recovered from the beverages, confirming the efficiency of the method proposed for lutein extraction. Based on literature data, 20mg of lutein per day is considered safe. The absence of any apparent adverse effect reported in published data available on clinical trials in humans and animals showeds that within the 
Table 1 - Physicochemical determinations and antioxidant activity of protein beverages.

\begin{tabular}{|c|c|c|c|c|}
\hline \multirow{2}{*}{ Determinations } & \multicolumn{4}{|c|}{ 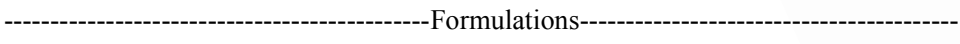 } \\
\hline & F1 & F2 & F3 & F4 \\
\hline $\mathrm{L}^{*}$ - luminosity & $43.06 \pm 0.27$ & $53.93 \pm 1.11$ & $67.20 \pm 0.14$ & $68.07 \pm 0.26$ \\
\hline $\mathrm{a}^{*}-$ red $v s$ green & $9.43 \pm 0.23$ & $11.09 \pm 0.13$ & $10.69 \pm 0.06$ & $10.01 \pm 0.13$ \\
\hline $\mathrm{b}^{*}$ - yellow vs blue & $26.67 \pm 0.33$ & $41.30 \pm 1.45$ & $49.72 \pm 0.27$ & $47.98 \pm 0.27$ \\
\hline $\mathrm{h}^{*}-$ hue angle $\left({ }^{\circ}\right)$ & $70.69 \pm 0.52$ & $74.95 \pm 0.58$ & $77.87 \pm 0.14$ & $78.21 \pm 0.11$ \\
\hline $\mathrm{C}^{*}$ - color saturation (chroma) & $28.25 \pm 0.31$ & $42.77 \pm 1.39$ & $50.86 \pm 0.25$ & $49.01 \pm 0.29$ \\
\hline $\mathrm{pH}$ & $4.08 \pm 0.05$ & $4.06 \pm 0.03$ & $4.13 \pm 0.01$ & $4.14 \pm 0.01$ \\
\hline Total soluble solids (Brix) & $21.63 \pm 0.20$ & $22.96 \pm 0.78$ & $24.60 \pm 0.70$ & $27.10 \pm 0.36$ \\
\hline Acidity (g citric acid $\left.\cdot 100 \mathrm{~g}^{-1}\right)$ & $0.36 \pm 0.02$ & $0.56 \pm 0.03$ & $0.76 \pm 0.02$ & $0.97 \pm 0.03$ \\
\hline Protein $\left(g \cdot 100 g^{-1}\right)$ & $0.58 \pm 0.02$ & $2.12 \pm 0.23$ & $4.13 \pm 0.38$ & $6.14 \pm 0.28$ \\
\hline Total carotenoids $\left(\mathrm{mg} \cdot 100 \mathrm{~g}^{-1}\right)$ & $2.46 \pm 0.09$ & $2.68 \pm 0.14$ & $2.57 \pm 0.08$ & $2.53 \pm 0.20$ \\
\hline Antioxidant activity $\left(\mu \mathrm{M}\right.$ Trolox $\left.\cdot \mathrm{g}^{-1}\right)$ & $0.10 \pm 0.002$ & $0.09 \pm 0.01$ & $0.11 \pm 0.01$ & $0.10 \pm 0.01$ \\
\hline
\end{tabular}

F1, F2, F3 and F4 formulated with $0.5,2.0,4.0$ and $6.0 \% \mathrm{w} / \mathrm{v}$ protein, respectively. Values represent the average of triplicates \pm standard deviation. The total carotenoid content was expressed as $\mathrm{mg}$ of lutein per $100 \mathrm{~g}$ of beverage.

recommended dose levels, lutein can be used as an ingredient in foods with a high degree of confidence in its safety (SHAO \& HATHCOCK, 2006).

The protein beverages had a considerable lutein content compared to foods in which lutein is naturally present. NACHTIGALL et al. (2007) evaluated the lutein content in some vegetables commonly consumed in the state of Minas Gerais (Brazil), including chard, watercress, wild chicory, azedinho, mustard, arugula and some unconventional vegetables, lobrobô, milkweed and taioba. Salad rocket had the highest lutein content at $5.12 \mathrm{mg} \cdot 100 \mathrm{~g}^{-1}$, the lobrobô also showed modest levels ranging from $3.50-4.76 \mathrm{mg} \cdot 100 \mathrm{~g}^{-1}$. Antioxidant activity of the drinks was approximately $0.10 \mu \mathrm{M}$ Trolox $\cdot \mathrm{g}^{-1}$. Similar values were reported by SOBRAL et al. (2016) on evaluating the antioxidant activity of a cheese dish supplemented with 16 and $32 \mathrm{mg} \cdot \mathrm{L}^{-1}$ lutein powder, which provided antioxidant activities of 0.10 and $0.24 \mu \mathrm{M}$ Trolox $\cdot \mathrm{g}^{-1}$, respectively.

\section{Microbiological evaluation}

The beverages had less than $1.0 \mathrm{CFU} \cdot \mathrm{mL}^{-1}$ E. coli, coliforms and $\boldsymbol{S}$. aureus, respectively. For the mesophilic aerobic and facultative anaerobic microorganisms, formulations F1, F2, F3 and F4 had counts ranging from $1.43 .6 \times 10^{2} \mathrm{CFU} \cdot \mathrm{ml}^{-1}$. As there is no specific legislation for protein beverages, the microbiological standards for dairy beverage legislation was consulted due to the similarity to the current whey protein formulations. The aerobic mesophilic and coliform counts were lower than the microbiological standards set for pasteurized dairy drinks, which allowed a maximum of two out of five analyzed samples, to contain $7.5 \times 10^{4}$ and $1.5 \times 10^{5} \mathrm{CFU} \cdot \mathrm{mL}^{-1}$ aerobic mesophilic and coliforms, respectively (BRAZIL, 2005).

The average counts of mesophilic aerobes and facultative anaerobes reported during the filling of the beverages was 1.1 and $1.8 \times 10^{2} \mathrm{CFU} \cdot \mathrm{cm}^{-}$ ${ }^{2}$. week $^{-1}$, respectively. These values should not exceed $30 \mathrm{CFU} \cdot \mathrm{cm}^{-2}$. week ${ }^{-1}$ in food processing environments (ANDRADE, 2008). Values reported were above the recommended limit. The processing environment may have contributed to the mesophilic aerobic count reported in the beverages.

\section{Sensory acceptability}

Figure 1 illustrates the internal preference map generated from the overall impression data of the protein beverages. Consumers are represented by points on the common abscissa and ordinate and linearly correlate the consumer with the main components. Correlation of the consumers with at least one component indicated differences in acceptance of formulations. On the preference map, consumers are located next to the products they preferred (SILVA et al., 2012a). The first and second principal components ( $\mathrm{PC1}$ and PC2) explained 54.32 and $26.14 \%$, respectively, of the acceptance data variance, together representing $80.46 \%$ (Figure 1A). For the color attribute, PC1 (54.36\%) and PC2 (26.66\%) explained a combined $81.02 \%$ of the color data variance (Figure 1B). Both the PC1 and PC2 were considered sufficient to discriminate the samples based on overall impression and color.

The spatial separation of the samples (Figure 1A) indicated three distinct groups for both the overall impression and color of beverages (Figure 


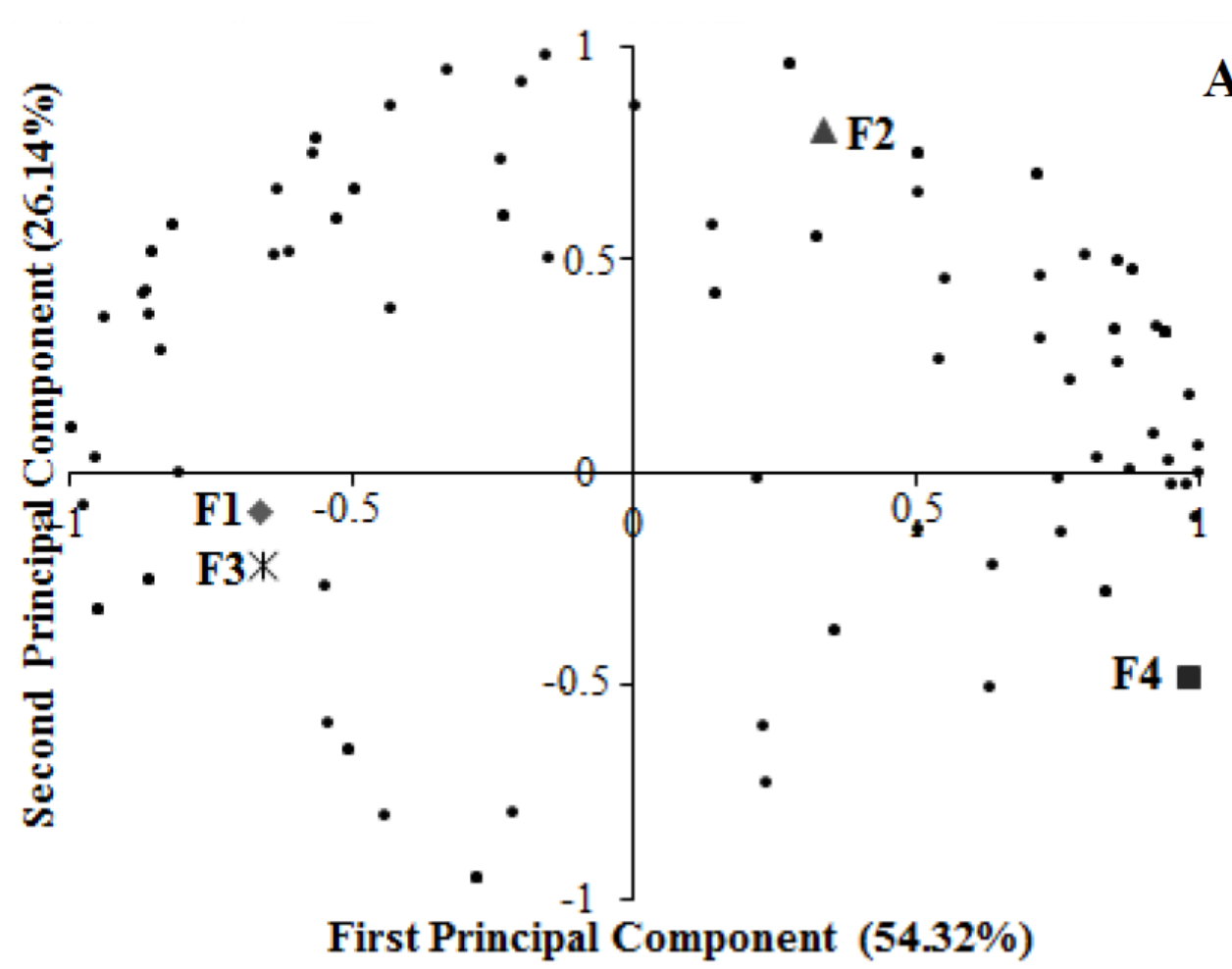

A

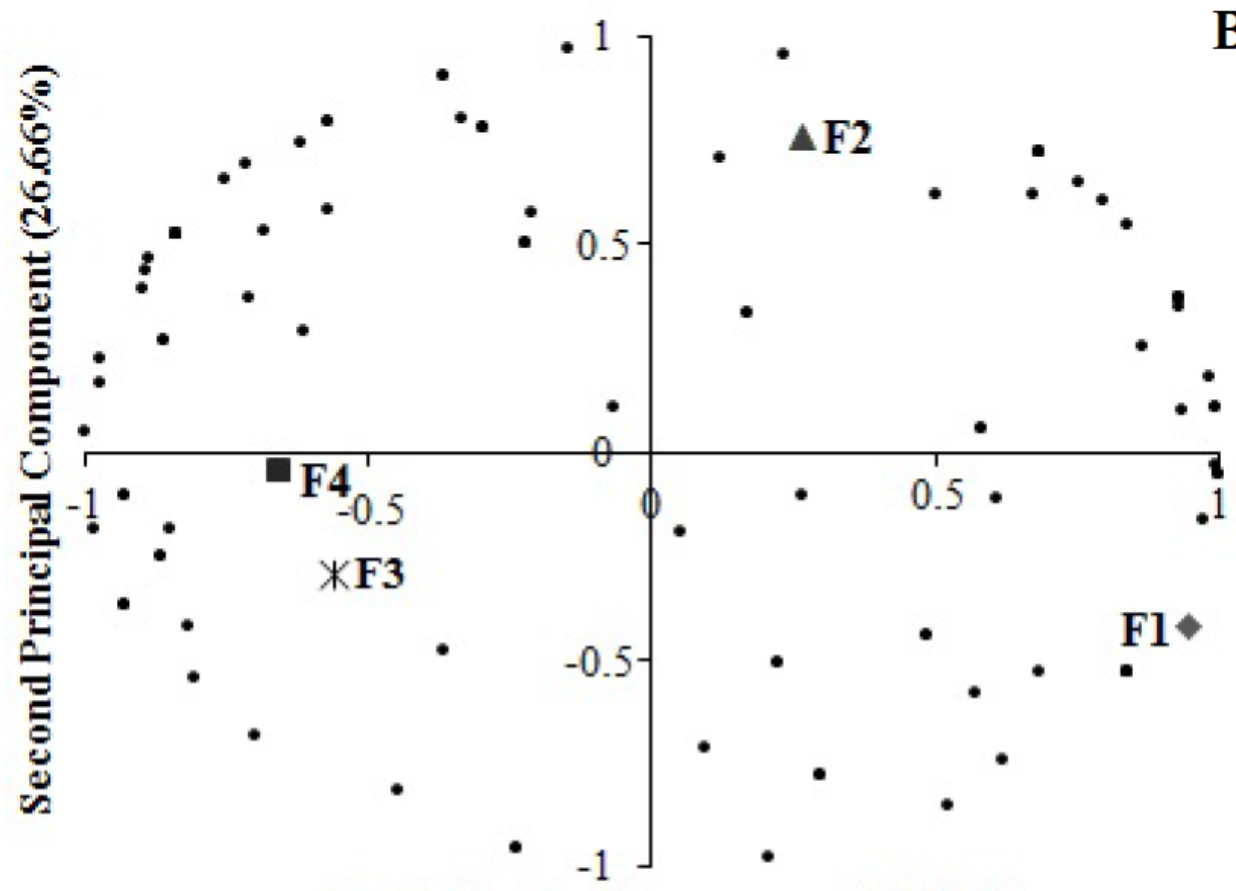

First Principal Component (54.36\%)

Figure 1 - Graphical representation of consumers preferences for the protein beverage formulations (F1, F2, F3 and F4) and based on the two main components, overall impression (A) and color (B). F1, F2, F3 and F4 formulated with 0.5 , $2.0,4.0$ and $6.0 \% \mathrm{w} / \mathrm{v}$ protein, respectively. 
1B). Spatial separation of the groups suggested by analysis of the global print data was similar to that indicated by the color data, differing only in the provision of two formulations. F2 was the preferred formulation, with a greater number of consumers positively correlated with F2 according to the two attributes evaluated. In the study by FELBERG et al. (2010) the preference map distinguished three groups of consumers that indicated acceptance of soy flavored coffee drinks varied based on the drink presentation (hot or cold) and consumption habits of the product by the evaluators. In the current study, the acceptance varied according to the amount of protein added to each formulation.

\section{CONCLUSION}

The acidity, soluble solids and colorimetric parameters of the beverages were influenced by protein content, which was brought about by differences in the protein amount used in the formulations. Beverages showed good sensory acceptance and F2, which contained $2.0 \% \mathrm{w} / \mathrm{v}$ protein, was the most preferred formulation for overall impression and color.

The protein content of the formulations is higher than other protein beverages available in the market and is considered high biological quality protein. Thus, the beverages formulated in this research showed potential marketability.

\section{ACKNOWLEDGEMENTS}

The authors are grateful for the company Tech Gemacon (Brazil) for supplying the commercial whey protein concentrate. The company Duas Rodas Industrial (Brazil) for providing aromas. The Fundação de Amparo á Pesquisa do Estado de Minas Gerais (FAPEMIG) for the fellowship. The Conselho Nacional de Desenvolvimento Científico e Tecnológico (CNPq) for financial support.

\section{BIOETHICS AND BIOSSECURITY COMMITTEE APPROVAL}

This study was approved by the Ethics Committee for Research with Human Beings of the Universidade Federal de Viçosa (registration: 26823514.4.0000.5153), Viçosa, MG, Brazil.

\section{REFERENCES}

ALVES, M. P. et al. Soro de leite: tecnologias para o processamento de coprodutos. Revista do Instituto de Laticínios Cândido Tostes, v.69, n.3, p.212-226, 2014. Available from: <http://dx.doi. org/10.14295/22386416.v69i3.341>. Accessed: September 10, 2015. doi: $10.14295 / 22386416 . v 69 i 3.341$

ANDRADE, N. J. Higiene na indústria de alimentos/controle da adesão microbiana e formação de biofilmes. São Paulo: Varela, 2008. 415p.
AOAC. Official Methods of AOAC International. Rapid Enumeration of Staphylococcus aureus in Selected Foods. Gaithersburg, USD. 2001. 200p.

BRASIL Ministério da Agricultura Pecuária e Abastecimento. Regulamento técnico de identidade e qualidade de bebida láctea. Instrução normativa $n^{\circ} 16$ de 23 de agosto de 2005. Diário oficial da União, Brasília, 24 de Agosto de 2005.

CHILDS, J. L. et al. Sensory properties of meal replacement bars and beverages made from whey and soy proteins. Journal of Food Science, v.72, n.6, p.425-434, 2007. Available from: <http://doi/1 0.1111/j.1750-3841.2007.00429.x>. Accessed: June 25, 2015. doi: 10,1111/j.1750-3841.2007.00429.x.

FELBERG, I. et al. Formulation of a soy-coffee beverage by response surface methodology and internal preference mapping. Journal of Sensory Studies, v.25, p.226-242, 2010. Available from: <http://doi/10.1111/j.1745-459X.2010.00278.x>. Accessed: June 28, 2015. doi: 10,1111/j.1745-459X.2010.00278.x.

IAL (INSTITUTO ADOLFO LUTZ). Normas analíticas do Instituto Adolfo Lutz: métodos químicos e físicos para análise de alimentos. 4. ed. São Paulo, 2008. 1020p.

IDF (INTERNATIONAL DAIRY FEDERATION). 20B:1993: Milk: determination of nitrogen content. Belgium, 1993. $11 \mathrm{f}$.

KATSANOS, C. S. et al. A high proportion of leucine is required for optimal stimulation of the rate of muscle protein synthesis by essential amino acids in the elderly. American Journal of Physiology, Endocrinology and Metabolism, v.291, p.381-387, 2006. Available from: $<$ https://www.ncbi.nlm.nih.gov/pubmed/16507602>. Accessed: July 17, 2015. doi: 10,1152/ajpendo.00488.2005.

NELSON, D. L.; COX, M. M. Lehninger principles of biochemistry. New York: W. H. Freeman, 2004. 1100p.

MINIM, V. P. R. Análise sensorial: estudos com consumidores. Viçosa: UFV, 2013. 332p.

NACHTIGALL, A. M. et al. Determinação do teor de luteína em hortaliças. Boletim do CEPPA, v.25, n.2, p.181-192, 2007. Available from: <http://dx.doi.org/10.5380/cep.v25i2.5205>. Accessed: July 20, 2015. doi: dx.doi.org/10.5380/cep.v25i2.5205.

PESCUMA, M. et al. Functional fermented whey-based beverage using lactic acid bacteria. International Journal of Food Microbiology, v.141, n.30, p.73-81, 2010. Available from: <https:// www.ncbi.nlm.nih.gov/pubmed/20483186>. Accessed: July 20, 2015. doi: 10.1016 / j.ijfoodmicro.2010.04.011.

RE, R. et al. Antioxidant activity applying na improved ABTS radical cation decolorization assay. Free Radical Biology and Medicine, v.26, p.1231-1237, 1999. Available from: <http://dx.doi. org/10.1016/S0891-5849(98)00315-3>. Accessed: June 20, 2015. doi: 10.1016/S0891-5849(98)00315-3.

ROBERTS, R. L. et al. Lutein and zeaxanthin in eye and skin health. Clinics in Dermatology, v.27, p.195-201, 2009. Available from: $<$ https://www.ncbi.nlm.nih.gov/pubmed/19168000>. Accessed: May 23, 2015. doi: 10.1016/j.clindermatol.2008.01.011.

RODÍC, Z. et al. Determination of lutein by high-performance thin-layer chromatography using densitometry and screening of major dietary carotenoids in food supplements. Journal of 
Chromatography A, v.1231, p.59-65, 2012. Available from: $<$ http:// www.sciencedirect.com/science/article/pii/S0021967312002117>. Accessed: May 28, 2015. doi:10.1016/j.chroma.2012.01.085.

RODRIGUEZ-AMAYA, D. B. A guide to carotenoid analysis in foods. USA: IISI Human Nutrition Institute, 2001. 64p.

SGARBIERI, V. C. Revisão: propriedades estruturais e físico-químicas das proteínas do leite. Brazilian Journal of Food Technology, v.8, n.1, p.43-56, 2005. Available from: <file://C:/Users/Usuario/ Downloads/proteinas do leite.pdf $>$. Accessed: June 28, 2015.

SHAO, A.; HATHCOCK, J. N. Risk assessment for the carotenoids lutein and lycopene. Regulatory Toxicology and Pharmacology, v.45, p.289-298, 2006. Available from: <https://www.ncbi.nlm.nih. gov/pubmed/16814439>. Accessed: July 13, 2015. doi: 10.1016/j. yrtph.2006.05.007.

SILVA, R. C.S. N. etal. Otimização da aceitabilidade sensorial de requeijão cremoso light. Ciência Rural, v.42, n.2, p.360-366, 2012a. Available from: $<$ http://dx.doi.org/10.1590/S0103-84782012000200027>. Accessed: July 25, 2015. doi: 10.1590/S0103-84782012000200027.

SILVA, V. M. Sorvete light com fibra alimentar: desenvolvimento, caracterização físico-química, reológica e sensorial. 2012b. $147 \mathrm{f}$.
Dissertação (Mestrado em Ciência e Tecnologia de Alimentos) Universidade Federal de Viçosa, MG.

SOBRAL, D. et al. Can lutein replace annatto in the manufacture of Prato cheese? LWT-Food Science and Technology, v.68, p.349-355, 2016. Available from: <http://dx.doi.org/10.1016/j. lwt.2015.12.051>. Accessed: June 25, 2016. doi: 10.1016/j. lwt.2015.12.051

STRINGHETA, P. C. et al. Luteína: propriedades antioxidantes e benefícios para a saúde. Alimentos e Nutrição, v.17, n.2, p.229-238, 2006. Available from: <http://serv-bib.fcfar. unesp.br/seer/index.php/alimentos/article/viewArticle/268>. Accessed: June 25, 2015

TAULIER, N.; CHALIKIAN, T. Characterization of $\mathrm{pH}-$ induced transtitions of $\beta$-LG: ultrassonic, densitometric, and spectroscopy studies. Journal of Molecular Biology, v.14, p.873-889, 2001. Available from: <https://www.ncbi.nlm.nih. gov/pubmed/11734004>. Accessed: June 25, 2015. doi: 10,1006/ jmbi.2001.5188.

WEHR, H. M.; FRANK, J. F. Standard methods for the examination of dairy products. 17.ed. Washington: American Public Health Association, 2004. 570p. 